\title{
Public Participation in Establishing Legal Policy to TNCs' Responsibility Upon the Violation of Right to Enjoy Healthy Environment in Indonesia
}

\author{
Sri Wartini and Jamaludin Ghofur \\ Faculty of Law Universitas Islam Indonesia Yogyakarta \\ Jln. Tamansiswa No. 158 Yogyakarta \\ sri.wartini@uii.ac.id.; james.fhuii@gmail.com.
}

\begin{abstract}
Public participation needs to be improved to promote an access to justice when the right to enjoy a healthy environment is violated by TNCs. This article has two problem formulations: first, how is public participation in making legal policy for the responsibility of TNCs. Second, why is it necessary to design a legal policy against the responsibility of TNCs for violating the right to enjoy a healthy environment is necessary to promote an access of justice. This research is normative. The approach used was the legislation and conceptual approach. The results of this study concluded that: first, public participation in the process of issuing a legal policy for the responsibility of TNCs in Indonesia has not been implemented properly. Second, the public participation in making the legal policy against the responsibility of TNCs for violating the right to enjoy a healthy environment is necessary to promote an access of justice.
\end{abstract}

Keywords: Human right, healthy environment, constitutional rights, transnational company, people participation

\begin{abstract}
Abstrak
Partisipasi publik perlu untuk ditingkatkan dalam rangka mempromosikan akses terhadap keadilan pada waktu hak untuk menikmati lingkungan yang sehat dilanggar oleh TNCs. Artikel ini memiliki dua rumusan masalah yaitu: pertama, bagaimana partisipasi publik dalam pembuatan kebijakan hukum atas tanggung jawab TNCs. Kedua, mengapa perlu untuk mendesain kebijakan hukum terhadap tanggung jawab TNCs atas pelanggaran hak menikmati lingkungan hidup yang sehat untuk mempromosikan akses terhadap keadilan. Penelitian ini merupakan penelitian normatif. Adapun pendekatan yang digunakan adalah pendekatan perundang-undangan dan pendekatan konseptual. Hasil penelitian ini menyimpulkan bahwa: pertama, partisipasi masyarakat dalam proses mengeluarkan kebijakan hukum untuk tanggung jawab TNCs di Indonesia belum dilaksanakan dengan baik. Kedua partisipasi publik dalam pembuatan kebijakan hukum terhadap tanggung jawab TNCs atas pelanggaran hak menikmati lingkungan yang sehat diperlukan untuk mempromosikan akses terhadap keadilan.
\end{abstract}

Kata-kata kunci: Hak asasi manusia, lingkungan yang sehat, hak konstitusi, perusahaan transnasional, peran serta masyarakat 


\section{Introduction}

The role of Transnational Corporations (hereinafter, TGNCs) in the host state is very important. TNCs is a unique actor who is often regarded as one of the sources that drive economic development in the host state, because of its ability to manage and to exploit natural resources, to create jobs for the society, increase tax revenues for the state, as well as stimulate the rising purchasing power of the citizens. On the one hand, TNCs carry out many activities that may cause environmental degradation and environmental pollution in the host state. Thus, in order to protect the national interest of the host state regarding the protection of the right to enjoy healthy environment needs a good policy from the host state government. It is necessary to involve public participation to promote access to justice in Indonesia, since there are many violations of right to enjoy healthy environment in Indonesia.

Public participation will depends on the mechanism that are provided by the government and based on the regulation which has been issued by the authority body. A number of national and international legal developments have led to the implementation of procedures to ensure the empowerment of private citizens in environmental decision-making processes. In practice, access to information affects decision-making process. Public participation, access to information, and access to justice are the three main pillars of the Aarhus Convention, which entered into force in October of 2001. ${ }^{1}$

Public procedural rights help educate and inform the public. A public that is predominantly concerned with making ends meet may view strong environmental institutions as a luxury, at least until environmental problems reach crisis levels. However, public access and exposure to environmental information, and vocal independent groups with expertise in environmental issues can be instrumental in bringing issues to the forefront of public discourse. An informed public is able to identify and address problems early on, before a crisis point is reached. Public input therefore may supplement scarce resources for monitoring, inspection, and enforcement of environmental law. Public input can help identify weaknesses or

1 Bende Toth, "Public Participation and Democracy in Practice Aarhus Convention Principles as Democratic Institution Building in The Developing World”, Vol. 30, J. Land Resources \& Envtl. L, (2010), at 295. 
issues with draft legislation. Where environmental risks are small, releasing relevant information to the public can help alleviate unfounded fears and stave off political risk. Relevant statistical and technical knowledge combined with a means for addressing environmental dangers through the courts create accountability mechanisms. ${ }^{2}$

In Indonesian context, the right to enjoy healthy environment is part of human rights which is stipulated on Article 28 Indonesian Constitution. Furthermore. It is also recognised in article 9 (3) Act No. 39 Year 1999 Regarding Human Rights. That is why, the right to enjoy healthy environment shall become the priority of the Indonesian government to protect it. ${ }^{3}$ Nonetheless, in order to achieve sustainable development, Indonesian government has to conduct three pillars of sustainable development, namely economic development, protection of the environment and sosial development, including the social justice. The three pillars of sustainable development have to be performed harmonizely. If only economic development becomes the priority while the other two pillars are ignored, the objective of sustainable development will not be achieved.

Indeed, in order to encourage public participation, it is necessary to provide objective and tranparant information to promote access to justice. When the government would like to issue a certain kind of regulation which may affect the right to enjoy healthy environment, the public has to be involved particularly when the government would like to establish legal policy to protect the right to enjoy healthy environment which has been violated by TNCs in Indonesia. Thus, the Indonesian government has to enforce the national law ${ }^{4}$ to protect the interest of its citizens.

The process of establishing national regulations in Indonesia is paramount to involve the public as the embodiment of legal development. It is urgent to involve the public in establishing the regulations as the legal implication of democratic system in Indonesia which is stipulated in Article 1 ( 2 ) of the 1945 Constitution which states, "Sovereignty is in the hands of the people and is implemented

${ }^{3}$ Absori, "Deklarasi Pembangunan Berkelanjutan dan Implikasinya di Indonesia", Jurnal Ilmu Hukum, Vol. 9, No. 1, Maret 2006: 39 - 52, UMS, Surakarta, at 40-41.

${ }^{4}$ http://pustaka.unpad.ac.id/archives/131720/, retrieved on 10 October 2015. 
according to this Constitution". In the establishment of a democratic legal system, the law-making process has to be bottom-up mechanism, which requires that substantive law is a reflection of the values and the willingness of the people. ${ }^{5}$

It is submitted that the paper analyzes how to enhance public participation in establishing a legal policy to the TNCs' responsibility for the violation of right to enjoy healthy environment in Indonesia, secondly, the paper is examined why it is necessary to design a legal policy to the TNCs's responsibility for the violation of rights to enjoy healthy environment to promote access to justice. Thirdly, the examination of the Challenges and Opportunities to enhance Public Partisipation to Promote Access to Justice. Finally, it is followed by conclusion.

\section{Problem Statement}

Based on the explanation, the problem Statement of the research are: first, how is the public participation in establishing a legal policy to the TNCs' responsibility for the violation of right to enjoy healthy environment in Indonesia? Second, Why is necessary to design a legal policy to the TNCs's responsibility for the violation of right to enjoy healthy environment to promote access to justice in Indonesia?

\section{Objective of the Research}

The objective of the research is to analyse public participation in establishing a legal policy to the TNCs' responsibility for the violation of right to enjoy healthy environment and to examine why it is necessary to design a legal policy to the TNCs's responsibility for the violation of right to enjoy healthy environment to promote access to justice in Indonesia.

\section{Research Method}

It is normative research. The methodology employed in this article is library-based research. It uses statutory approach and conceptual approach. While the main research materials used in the research are primary and secondary sources. The primary sources consist of International instruments, such as Aaheurs Convention,

${ }^{5}$ H. Bomer Pasaribu, Arah Pembangunan Hukum Menurut UUD 1945 Hasil Amandemen Dari Perspektif Legislasi, Majalah Hukum Nasional, Badan Pembinaan Hukum Nasional Departemen Hukum dan HAM RI, 2007, at $164-165$. 
and Rio Declaration, while the national regulations consist of Indonesian Constitution, Act No. 32 /2009, regarding Environmental Protection and Management, Act No. 39/1999 regarding Human Right, Act, No. 14/ 2008 regarding the Outspokenness Openness of Public Information, Act. No. 25/ 2009 regarding Public Services and Act No. 12/2012 regarning the Indonesian regulation System. While the secondary sources consist of books, Journal, report and internet which are relevant to the subject matter.

\section{Discussion and Result}

\section{Access to Justice in International Instruments}

Access to justice is in every aspect of life is very important for the citizen both in developed and developing countries. In the case of the right to enjoy healthy environment which has been recognized as part of human right is necesasry and obligatory for state to protect the riht and provide appropriate access to justice when the right to enjoy healthy environment has been violated. Access to justicve is one of the human rights which has been regulated in international level and national level. "Access to justice" is a broad term that can be defined in different ways.

Yet, traditionally and for the most part, increasing access to justice has been related to increased access to legal counsel. Having access to representation by an attorney is considered a central means to increase individuals' access to justice, i.e., access to legal institutions or to legal solutions to their problems. ${ }^{6}$ In the case of the violation of the right to enjoy healthy environment which has been conducted by TNCs has to be protected by the law and has to be provided a certain mechanism how to have access to their remedy. Access to justice to the right of healthy environment in international instruments can be traced back to International Environmental Law, while in national instruments can be found in national environmental law as well as the human right law.

The Principle 11 of the Rio declaration on Environment and Development recalls that "States shall enact effective environmental legislation", and the

\footnotetext{
${ }^{6} \mathrm{Wu}$ Changhua, "Improving The Legal And Policy Foundation For Public Access To Environmental Information In China,” Vol, 24, Temp. J. Sci. Tech. \& Envtl. L (Spring, 2005), at. 291.
} 
Principle 10 states that "Effective access to judicial and administrative proceedings, including redress and remedy, shall be provided". The recently adopted Resolution of the UN General Assembly on the Rule of Law (A/RES/67/1 24 September 2012) recalls that " the advancement of the rule of law at the national and international levels is essential for sustained and inclusive economic growth, sustainable development, the eradication of poverty and hunger and the full realization of all human rights and fundamental freedoms, including the right to development, all of which in turn reinforce the rule of law, and for this reason we are convinced that this interrelationship should be considered in the post-2015 international development agenda."

In 2002 in Johannesburg, the First Global Judges Symposium acknowledges the positive developments of environmental justice, especially in developing countries. In 2012, at Rio+20, over 250 of the world's Chief Justices, Attorneys General and Auditors General adopted the Rio+20 document entitled 'The Future We Want'. In this contribution, judges proposed Principles for the Advancement of Justice, Governance and Law for Environmental Sustainability which include "accessible, fair, impartial, timely and responsive dispute resolution mechanisms".7

Access to justice in environmental matters is not conceived as one model or one set of rules to be applied uniformly. It can take different forms and adaptations depending on the specific legal traditions and the national legal systems. It could stress the role of Alternative Dispute Resolution. It could adopt different balances between administrative proceedings and judicial proceedings. It could rely on Specialized Environmental Courts or Boards. It could include the use of class-actions with various forms. Regional conventions, such as the Århus convention (UNECE), may also play an important role in guaranteeing access to justice in environmental matters and in developing specific international control mechanisms.

Environment non-governmental organizations play an essential role as regard expertise for preservation of the environment. They defend also the interests of nature and therefore could complement the State action through awareness raising, education and protection of the environment. Being often confronted to threats to 
the environment, these organizations should be granted legal standing in order to compensate the lack of interest in implementation of environmental law outside the governmental bodies due to the absence in many environmental cases of direct threats to human health, property or even economic values. This does not preclude States to define national rules for limiting access to justice to organizations presenting guarantees and based on genuine environmental interests. ${ }^{8}$

Based on many cases that occurred in international community has already become the triggering factor to involve public into decicion making prosess and also in theestablishing of legal policy to protect the right of healthy environment to promote access to justice. The Aaheurs Convention has thee pillars of public participation in order to promote access to justice, namely:

1. Access to information: any citizen should have the right to get a wide and easy access to environmental information. Public authorities must provide all the information required and collect and disseminate them and in a timely and transparent manner. They can refuse to do it only under particular situations (such as national defence)

2. Public participation in decision making: the public must be informed over all the relevant projects and it has to have the chance to participate during the decisionmaking and legislative process. Decision makers can take advantage from people's knowledge and expertise; this contribution is a strong opportunity to improve the quality of the environmental decisions, outcomes and to guarantee procedural legitimacy.

3. Access to justice: the public has the right to judicial or administrative recourse procedures in case a Party violates or fails to adhere to environmental law and the convention's principles.

The Aarhus convention is a "proceduralisation of the environmental regulation",it focuses more on setting and listing procedures rather than establishing standards and specifying outcomes, permitting the parties involved to interpret and implement the convention on the systems and circumstances that characterize their nation. This model embodies a perfect example of a multi-level governance. The risk could lay in a loss of time and resources that could be

${ }^{8}$ Open Working Group on Sustainable Development Goals (United Nations), “Access to Justice in environmental matters for sustainable development Contribution of the Société de Legislation Comparée to the Open Working Group on Sustainable Development Goals (United Nations)", http://www.legiscompare.fr/siteweb/IMG/pdf/A2J_SLC.pdf Retrieved on 10 October 2015. 
otherwise invested in defining the outcomes, notwithstanding the fact that it renders the convention vague, weak and open to multiple interpretations.

\section{Legal Policy to Protect the Right of Healthy Environment in Indonesia}

In the literature of jurisprudence, legal policy is synonymous with the political law. As stated by Muhammad Akib that etymologically legal political term is a translation of the Dutch legal term rechts politiek, which is formed from two words: recht and politiek. In the Indonesian word "recht" is law, whereas a political word in it contained was the meaning of a regulation, which is usually translated as wisdom or policy ${ }^{9}$. Therefore, the term legal and political policy of the law is comparable terminology and used interchangeably to refer to the same meaning.

Moh. Mahfud MD in his book Politics of Law in Indonesia defines law as a legal political policy or the law that will be applied to establish the new law as well as the replacement of the old law in order to achieve the objectives of the State. Thus, the law is a political choice about the laws that will be enforced at the same choices about the laws that will be revoked or not enforced, all of which are intended to achieve the objectives of the state which is stupulated in the preamble of the 1945 Constitution. ${ }^{10}$

The legal policy in order to manage the environment or to create a healthy environment may vary from one state to another. It was largely determined by the level of commitment of each state. If it is observed, there are countries whose policies set forth in the constitution environmental laws with different variants of settings, but there are also only set at the level of legislation under the Constitution.

According to Mas Achmad Santosa, the commitment of state in ensuring the protection of the environment can be classified as follows:

1. The Highest Commitment

The recognition of right for nature which is supported by subjective rights and the duty of the states in the management of environment which is in line with the development based on sustainable development principle in the form of environmental charter or charter for nature.

9 Muhammad Akib, Politik Hukum Lingkungan: Dinamika dan Refleksinya Dalam Produk Hukum Otonomi Daerah, PT RajaGrafindo Persada, Jakarta, 2012, at 1.

${ }^{10}$ Moh. Mahfud MD, Politik Hukum, Edisi Revisi, Rajawali Pers, Jakarta, 2009, at 1. 
2. The High Commitment

The recognition of subjective rights which is supported by duty of the states in the management of environment which is in line with the development in the special sceme, namely environmental charter.

3. Adequate Commitment

Subjective recognition of rights to the duty of the states in the field of environmental management in specific provisions (not superimposed or mixed with the fundamental rights of others). This category as well as a second category recognizes the rights of citizens and the state's obligation, but it does not contain directions or patterns of development.

4. Medium Commitment

Subjective recognition of rights without acknowledging the specific duty of the states in the field of environmental management, but there is a charge on the pattern and direction of sustainable development, although it is not placed in special chapters but it is mixed with other fundamental rights. This category also includes countries that its Constitution only recognises Subjective right or duty of the states are mixed with other fundamental rights.

5. Low commitment

This category refers to a Constitution that does not acknowledge the norms of environmental law (subjective rights and the duty of the state) and the pattern and direction of development. ${ }^{11}$

Indonesia has already established legal policies relating to the management of natural resources in order to conduct properly in accordance with the principle of sustainable development (sustainable development). The highest regulation of it is established in the 1945 Constitution. The wording is enshrined in the Preamble, Article 33 paragraph (3) and (4) and Article 28H 1945.

Section Fourth Preamble of the 1945 Constitution has determined the purpose of the state and the formation of the government of Indonesia is to promote the general welfare are to achieve this, the 1945 provides exclusive rights to the state's control over natural resources, especially with regard to the life of many people which is controlled by the state . Exclusive rights management of natural resources is provided for in Article 33 UUD 1945 which states :

(1) The economy shall be organized as a common Endeavour based upon the principles of the family system.

(2) Sectors of production which are important for the country and affect the life of the people shall be under the powers of the State.

${ }^{11}$ Jimly Asshiddiqie, Green Constitution: Nuansa Hijau Undang-Undang Dasar Negara Republik Indonesia Tahun 1945, Rajawali Pers, Jakarta, 2010, at v-vi 
(3) The land, the waters and the natural resources within shall be under the powers of the State and shall be used to the greatest benefit of the people.

(4) The organization of the national economy shall be conducted on the basis ofeconomic democracy upholding the principles of togetherness, efficiency with justice, continuity, environmental perspective, self-sufficiency, and keeping a balance in the progress and unity of the national economy.

(5) Further provisions relating to the implementation of this article shall beregulated by law.

The provisions of Article 33 The 1945 Constitution implies that the implementation of the national economy should be organized based on economic democracy with several principles including the principle of sustainable, environmentally sound, and the balance of progress. In addition, Article 33 The 1945 Constitution also link the national economic development and the environment. So the basic principle of development adopted today should be able to harmonize economic, social, and protection of the environment.

In addition to Article 33 , another chapter related to the constitutional guarantee of the right to a healthy environment regulated in Article $28 \mathrm{H}$ paragraph ( 1 ) of the 1945 Constitution which reads : Everyone has the right to live physical and spiritual prosperity, reside and obtain a good living environment and healthy and receive medical care.Thus, constitutionally, the Preamble, Article 33 and Article 28H ( 1 ) 1945 is the reference and objectives to be achieved in environmental management in Indonesia, namely the management of the environment for the maximum interests and prosperity of the people of Indonesia to keep the preservation of nature. Therefore, the 1945 Constitution as the supreme law in Indonesia must become a fundamental guideline in designing policies on environmental law in Indonesia.

Therefore, it must be admitted that the 1945 Constitution still contains weaknesses and yet provide an ideal setting for environmental management as merely set it in outline. However, the Indonesian Constitution 1945 has laid the political foundation of environmental management law is strong enough to become the highest reference in the establishment, implementation, and enforcement of environmental law. According to Muhammad Akib, as the supreme law of politics, then all the legal policies relating to environmental management, including in the 
context of the implementation of regional autonomy, should reflect the shades of green in a legal product. If not, then it opens the possibility to do constitutional review to the Constitutional Court.

In order to realise the principles of natural resource management in Indonesia as mandated by the Constitution. The government has set legal political management and protection of the environment - especially in mining - as outlined in various laws such as Act No. 32 of 2009 on protection and Environmental Management Article 12,12 Law No. 4 of 2009 on Mineral and Coal Mining Art 2 and article 3 state the Principle and objective of the Mineral and Coal Mining. ${ }^{13}$ Law No. 25 of 2007 on Investment Article, and Law No. 40 Year 2007 regarding Limited Liability Company. Article 16 point (d) of Law No. 25 of 2007 on Investment oblige the investor to preserve the environment. While the provisions of Article 17 it states, "investors exploiting natural resources that are not renewable gradually must allocate funds for the recovery location that meets the standards of environmental feasibility, the implementation of which is set in accordance with the provisions of the legislation" transparance.

Meanwhile in Article 74 paragraph ( 1 ) to paragraph ( 3 ) of Law Number 40 Year 2007 regarding Limited Liability Company stated, the Company runs its business activities in the field and / or related to the natural resources required to implement social responsibility and the environment. Social and environmental responsibility is the obligation of the Company budgeted and accounted for as expenses of the Company that the implementation is done with due regard to

12 (1) Natural resources shall be utilized on the basis Of RPPLH; (2) If RPPLH as referred to in paragraph (1) has not been formulated, natural resources shall be utilized on the basis of the support and carrying capabilities of the environment by regarding: a. the continuation of environmental processand function; $b$. the continuation of environmental productivity; and c. safety, living standard and welfare of communities; (3) The support and carrying capabilities of the environment as referred to in paragraph (2) shall be stipulated by: a. the Minister, in the case of the support and carrying capabilities ofnational and insular/archipelagic environment; b. governors in the case of the support and carrying capabilities of provincial environment and inter-regency/clty ecoregion; or c regents/mayors in the case of the support and carrying capabilities of the regent/municlpal environment and ecoregion in a regency/ city. (4) Further provision on procedures for stipulating the support and carrying capabilities of the environment as referred to in paragraph (3) shall be governed by a government regulation.

13 Article 2 on Mineral and Coal Mining Act stipulates that the principle of coal and mining are (a) utility, justice and balance; (b) support the national interest; (c) participative, tranparant andaccountability; (d) sustainability and environmentally sound. While Article 3 on Mineral and Coal Mining Atc stipulates thatin order to support the sustainability of national development, the objective of miniral and coal mining management are to guarantee the efectiveness of mineral and coal mining, environmentally sound and sustainability of the mineral and the coal as the raw material or as the source of national energy, to support and to enhance the capability to compete in national, regional and international level and also to ensure the legal certainty of mineral and coal minig activities. 
decency and fairness. Company which does not carry out these obligations be sanctioned in accordance with the provisions of the legislation .Law No. 32 of 2009 on the Protection and Management of the Environment as a fundamental rule in environmental management in Indonesia has set up protection measures and environmental management that aims to protect the health of the environment in order to create a healthy environment for all citizens.

\section{International Instrument to Regulate Public Participation}

The principle of public participation in international environmental law can be traced back to the 1992 Rio Declaration and its Agenda 21. According to Agenda 21 , one of the fundamental prerequisites for the achievement of sustainable development is broad public participation in decision-making. Furthermore, in the more specific context of environment and development, the need for new forms of participation has emerged. This includes the need of individuals, groups and organizations to participate in environmental impact assessment procedures and to know about and participate in decisions, particularly those which potentially affect the communities in which they live and work.

Especially in Principle 10 of the Rio Declaration laid the groundwork for what later would become the Aarhus Convention through the wording that:

"environmental issues are best handled with the participation of all concerned citizens, at the relevant level. At the national level, each individual shall have appropriate access to information concerning the environment that is held by public authorities ... and the opportunity to participate in decision-making processes. States shall facilitate and encourage public awareness and participation by making information widely available."

These principles were adopted by no less than 172 nations and subsequently incorporated in several MEAs. For example, Article 6 of the United Nations Framework Convention for Climate Change ("UNFCCC") provides that "parties shall promote and facilitate ... public participation in addressing climate change and its effects and [in] developing adequate responses." Similarly, the UNECE Convention on Environmental Impact Assessment in a Transboundary Context ("Espoo Convention") calls for Parties to provide "an opportunity to the public in the areas likely to be affected to participate in relevant environmental impact 
assessment procedures regarding proposed activities. The Protocol on Water and Health to the Convention on the Protection and Use of the Transboundary Watercourses and International Lakes incorporates public participation as well.

Access to information, public participation in decision-making and access to justice in environmental matters is governed at international level by the so-called Aarhus Convention, signed in Aarhus (Denmark) in 1998.The Aarhus Regulation grants the public rights and imposes obligations on Community institutions and bodies regarding access to environmental information public participation concerning plans and programmes relating to the environment and access to review procedures.

Environmental information covers any available information, in any form or format, on the environment itself, its elements (air, water, soil, land, landscape and natural sites, marine areas, etc.) and its various components, as well as information concerning factors, such as substances, energy, noise, radiation or waste, including radioactive waste, emissions, discharges and other releases, affecting or likely to affect the environment. Environmental information also includes measures, such as policies, legislation, plans, programmes, and activities affecting or likely to affect the environment as well as measures or activities designed to protect it; cost-benefit and other economic analyses used to prepare those measures and activities are covered as well. Information on the state of human health and safety, conditions of human life, cultural sites and built structures, when influencing or influenced by the environment, and reports on the implementation of environmental legislation also constitute environmental information.

Why is public participation necessary or even desirable? After all, it is the job of our governments and elected representatives to assess and balance competing interests and resources, taking everyone's best interests into account? Do the advantages of public participation outweigh the disadvantages? How might the democratic systems be improved by public participation? And what is public participation at its core? As a threshold matter, public participation in government decision making is based on the belief that those who are affected by a decision have a right to be involved in the decision-making process. The core values and beliefs supporting public participation are: 
(1) Public participation includes the promise that the public's contribution will influence the decision.

(2) Public participation promotes sustainable decisions by recognizing and communicating the needs and interests of all participants, including decision makers.

(3) Public participation seeks out and facilitates the involvement of those potentially affected by or interested in a decision.

(4) Public participation seeks input from participants in designing how they participate.

(5) Public participation provides participants with the information they need to participate in a meaningful way.

(6) Public participation communicates to participants how their input affected the decision. ${ }^{14}$

According to Saut P. Panjaitan, participation and community involvement in the planning process of public policy and public policy programs is one of the characteristics of a democratic state administration. Thus, Indonesia as a democratic state must apply this principle in the formulation and preparation of public policy. ${ }^{15}$ Moreover, there are several benefits that can be gained on public involvement in policy-making, namely : First, supporting the realization of the principles of transparency and accountability. Second, ensuring that the views and arguments for policies that would be born so as to make these policies become more qualified. Third, create a policy is more likely to be accepted by society. Fourth, the costs used in the manufacturing becomes more efficient. And fifth, to minimize the negative response of the public to have an impact on political stability. ${ }^{16}$

In the 1992 Rio Declaration on Environment and Develop-ment ("Rio Declaration"), the international community recognized that sustainable development depends upon good governance. Principle 10 of the Rio Declaration sets out the fundamental elements for good environmental governance in three "access rights": 1) access to information, 2) public participation, and 3) access to justice. This principle is

${ }^{14}$ Marianne Dellinger, “Ten Years Of The Aarhus Convention: How Procedural Democracy Is Paving The Way For Substantive Change In National And International Environmental Law”, Vol. 23, Colo. J. Int'l Envtl. L. \& Pol'y, (Summer 2012), at 312.

${ }^{15}$ Saut P. Panjaitan, "Jaminan Perlindungan Konstitusional Hak Tiap Orang Untuk Memperoleh Informasi dan Berkomunikasi”, Jurnal Simbur Cahaya, Vol. XV No. 42 Mei 2010, Unit Penelitian FH Universitas Sriwijaya Palembang, hlm. 1957-1958

16 Johan Kurniawan, Transformasi Partisipasi Publik dalam Perumusan Kebijakan di Era Reformasi, terdapat dalam http://setkab.go.id/transformasi-partisipasi-publik-dalam-perumusan-kebijakan-di-erareformasi/, diakses tanggal 20 Agustus 2016. 
based on the experience that, where governmental decision-making fails to include these essential tenets of access, the outcomes are more likely to be environmentally damaging, development ally unsustainable, and socially unjust.

Access rights facilitate more transparent, inclusive, and accountable decisionmaking in matters affecting the environment and development. Access to information empowers and motivates people to participate in an informed and meaningful manner. Participatory decision-making enhances the ability of governments to respond to public concerns and demands, to build consensus, and to improve acceptance of and compliance with environmental decisions because citizens feel ownership over these decisions. Access to justice facilitates the public's ability to enforce their right to participate, to be informed, and to hold regulators and polluters accountable for environmental harm. ${ }^{17}$

The access rights in the Rio Declaration have been widely recognized across the world. However, much work remains to ensure that these rights are truly available to empower societies. Commitments made by governments to the principles of good governance under the Rio Declaration, Agenda 21, and the Johannesburg Plan of Implementation need to be strengthened, monitored, and reported upon. Governments that have not already done so must establish legal rights to access to information, public participation, and justice. Finally, all governments must demonstrate their support for the protection of these rights. Once access rights are established, governments and civil society need to focus on developing the capacity to operationalize these rights and make them meaningful for the communities they are intended to support.

The outcome of the United Nations Conference on Sustainable Development ("UNCSD," also known as the "Rio 2012 Summit" or "Rio 2012") must include an affirmation of these fundamental access rights and that substantial efforts must be made to establish them and make them enforceable in all countries. At a minimum, national governments must commit to the full implementation of access rights as national law, ensure intergovernmental organizations and institutions incorporate these rights into their own regulation and practices, and develop international and

${ }^{17}$ David Banisar et all, "Moving From Principles To Rights: Rio 2012 And Access To Information, Public Participation, And Justice”, Sustainable Dev. L. \& Pol'y, (Spring, 2012), at 8-9. 
regional mechanisms to monitor the implementation of these practices. New international instruments are necessary to ensure that these access rights are truly available to everyone.

\section{Publict Participation in Establishing Legal Policy to the TNCs' Responsibility upon the Violation of Right to Healthy Environment}

Public participation is very importan in establishing legal policy to the violation of right to enjoy healthy environment. When the public involve in establhising the legal policy, the government will be aware that it is necessary to protect the interest of the public. The right to enjoy healthy environment has been recognized as part of human right and as a constitutional right of the public need to be protected. When there is a violation of the right, thre must be available to get the remedy. Thus, the public has to have access to justice from the violation of right to enjoy healthy environment. Hence it is mandatory to enhance public participation in establishing legal policy.

The fundamental legal basis of the necessity of public participation in all policymaking State including the law on the responsibility of TNCs policies in violation of the right to enjoy healthy environment in Indonesia is Article 1 (2) of the 1945 Constitution, namely ; Sovereignty belongs to the people and carried out in accordance with the Constitution. As revealed by Saut P. Panjaitan that participation and community involvement in the planning process of public policy making, public policy programs, public decision-making process and reasons of public decisionmaking is one of the characteristics of a democratic state administration. 18

The legal protection and and the legal guarantee of the society to partipate in establishing state policy can be found in various act in Indonesia, such as :

1. Law No. 39 regarding Human Rights

Article 100 : Any person, group, political organizations, community organizations, non-governmental organizations, or other social institutions, are entitled to participate in the protection, enforcement and promotion of human rights.

Article 102 : Any person, group, political organizations, community organizations, non-governmental organizations, or other social

\footnotetext{
${ }^{18}$ Saut P. Panjaitan, "Jaminan Perlindungan Konstitusional Hak Tiap Orang Untuk Memperoleh Informasi dan Berkomunikasi”, Jurnal Simbur Cahaya, Vol. XV No. 42 Mei 2010, Unit Penelitian FH Universitas Sriwijaya Palembang, hlm. 1957-1958
} 
institutions, are eligible to submit proposals concerning the formulation and policies related to human rights to the Human Rights Commission and other institutions

2. Law No. 12 Year 2011 on the Establishment of Laws and Regulations.

Article 96 states : Public Participation

(1) The public may contribute to the issuing of Act whether it presents orally or in written form.

(2) The oral or written contribution whiichg is mention in paragraph (1) can be conducted through public hearing; work visiting, socialisation or seminar/discussion.

(3) The public which is meant by paragraph (1) is individual or a group of people who have interest to the substance of the Act.

(4) In oreder to make easier the public contributes orally or in written in the process of issuing Act as mentioned in paragraph (1) every planning Act must be easy to be accessed by the public.

3. Law No. 14 of 2008 on Public Information

Article 3 states that the purpose of this Act the establishment of which is to guarantee the right of citizens to know the plan of public policy, public policy programs , and public decision-making process as well as the reason for making a public decision. In addition, to encourage public participation in the public policy making process and improving the community's active role in making public policy.

4. Law Number 25 Year 2009 on Public Service

Article 4 letter (f) : The implementation of the public service is based on a participatory, where the explanation of this article mentions that the participation is Increasing community participation in the provision of services by taking into account the aspirations, needs, and expectations of society

5. Act No. 32 of 2009 on the Protection and Management of the Environment Article 70 : (1) The public has the same rights and opportunities and the broadest to play an active role in the protection and management of the environment.

(2) The role of the community can be: a. social supervision; $b$. provision of advice, opinions, suggestions, objections, complaints; and / or c. delivery of information and / or reports.

(3) The role of the public made to : a. increase awareness in environmental protection and management; $b$. increase selfreliance, community empowerment, and partnerships; c. cultivate the community capacity and initiative; $d$. cultivate the community responsiveness to social control ; and f. develop and maintain the culture and local wisdom in the framework of environment conservation .

There are sufficient legal basis for public participation, the questions are how to enhance partcipation in establishing legal policy to the TNCs' who has already 
violated the right to enjoy healthy environment. There are some mechanism how to enhance public participation in establishing legal policy in Indonesia, such as :

Firstly, the government has to issue certain guide line how to participate in establishing legal policy. There must be a transparent information available for the public regarding the policy which is applicable to TNC's responsibility. Secondly, the government has to provide institutions that are going to accept the opinion of the public regarding the legal policy. Thirdly, educate the society how to participate in establising legal policy. Fourth, the government has to provide mechanism how to participate in establishing legal policy

\section{The Mechanism of Public Participation in Indonesia in Establishing Legal Policy}

There is no one standard pattern of how the implementation mechanisms for public participation in Indonesia. Various legislation only stipulates the obligation for the government to engage public participation in any policy making, especially in terms of legal policy. Public participation can be done in various models. Saifuddin in his book, public participation in the formation of legislation to divide at least 4 models of public participation. ${ }^{19}$

1. Pure Representative Democracy

In this model, the nature of public participation still "pure ". That is, the people as citizens in a democratic State involvement in public decision-making is done by representatives elected by universal suffrage. In this case, people only lived accept what will be produced by the legislature in the formation of the Act. Thus, citizen participation is limited, namely through elections conducted periodically. Public decision making process is only done by the legislature, while the only people involved in the establishment of representative institutions.

2. A Basic Model of Public Participation

The people have interaction in the decision-making process, not only through elections but in the same time also make contact with the representative institutions. Nevertheless this model can not be said as the shape and nature of the actual interaction. In this model, people who may have had contact with representative institutions. That is, there are no restrictions on the notion of "public". Thus every citizen who has reached a certain age, for example 18 years, may be involved in public participation to express their aspirations. But in the delivery of public aspirations is the representative body seemed to open a dialogue.

${ }^{19}$ Saifudin, Partisipasi Publik Dalam Pembentukan Peraturan Perundang-Undangan, FH UII Press, Yogyakarta, 2009 , at $177-184$ 
3. A Realism Model of Public Participation

In this model, actors and public participation tends to be dominated by the interest groups and other organizations are organized.Public, in addition to participating in the elections also interact with representative institutions. But here is not all citizens carry out public participation in the form of establishing contact interaction with representative institutions. Actors of public participation has led to interest groups and other organizations are organized. Thus there is a tendency to understand the 'public' in a limited context. In this model there was a recognition that the public as a whole may not be involved in the process of formation of the Act directly. Thus, the understanding of the word 'realism' is to show the limitations in conducting public participation that is only done by interest groups and organizations are organize

4. The Possible Ideal for Public Participation

The alternative model was introduced as the fourth form of a variety of community participation, is an extension of incorporating three groups of participants, namely: those who are organized and strong; Those who are organized but weak; and Reviews those who are weak and unorganized. By applying this model, the government can develop a strategic vision that can be addressed to all three groups together. In this model, in turn, gave rise to two additional dimensions, namely : a) the dimensions of the role of political parties and the majority party; b) dimensional representation relationship with the executive .

Ideally, the mechanism of society participation in policy-making involve the broadest community both individually and collectively as the fourth model. If the stages of preparation of the legislation include the planning, design, discussion, approval, enactment, implementation, and evaluation, the space for public participation should exist in each of these stages. Thus, it is expected to be born legal policy participatory, critical society, and governments that are responsive to social needs. Public participation is not only necessary in the formulation of legal policy, but in all phases of its formation until the evaluation. While the public participation mechanism in establishing legal policy in Indonesia has not yet conducted properly. It needs to enhance and to design the mechanism.

\section{The Challenges and Opportunities to enhance Public Partisipation to Promote Access to Justice}

There are many cahllenges and oportunities how to enhance public participation and access to justice in Indonesia.Indonesian -adopted the Freedom of Information Act (Act No. 14 of 2008 on Public and hereafter FOIA, and it came into force on 1 May 2010. The Act Provides a legal guarantee for access to information held by 
public bodies, and requires public bodies to publish information proactively as well as to release information upon request. ${ }^{20}$

In Indonesia the public participation especially in the establishing of legal policy to the responsibility TNCs upon the violation of right to healthy environment facing many obtacles. The obtacles do not only come from the government but also from the public. Since there are many obtacles in accessing the information so that it causes lack of public participation and causes a hinder in accessing justice. The obtacles to enhance public participation in order to easyly access to justice need to be conducted seriously. Namely: (i) Weak of public awareness; (ii) there is no legal mechanism; and (iii) Lack of supporting facilities from the government.

On the Other hand, opportunities to enhance Public Partisipation to Promote Access to Justice in Indonesia as followed: (i) Increasing public awareness; (ii) providing the legal mechanism; and (iii) Providing the facilities to conduct paublic participation. Furthermore, the government has to provide the mechanism to access to justice for remedy for the parties whose right has been violated.

\section{Conclusion}

Public participation is one of the instruments how to provide access to justice to the society. There are many violations that have been done by TNCs which violated the right to enjoy healthy environment as constitutional right and as part of human right in Indonesia. Indeed, there is no direct participation of the public in the process of issuing legal policy to the responsibility of TNCs in Indonesia. There are many activities that have been done by TNCs without any participation of the public who are affected by the activities. The mining activities often cause pollution or environmental degradation sorrounding the mining activities, so that , the right to enjoy healthy environment especially who live sorrounding the mining activities has been violated. Thus, the public participation especially in the process of issuing legal policy to the responsibility of TNCs is necessary to

${ }^{20}$ TIFA, “Fulfilling the Right to Information Baseline Assessment on Access to Information in East Nusa Tenggara”, https://www.article19.org/data/files/pdfs/publications/fulfilling-the-right-to-information.pdf. Retrieved on 10 October 2015. 
promote access to justice. However, the public participation in the process of issuing legal policy to the responsibility of TNCs in Indonesia has not yet carried out properly. It is necessary to provide an appropriate mechanism and to enhance the awareness of the society to be more active to participate in the process of issuing legal policy to the responsibility of TNCs in order to promote access to justice in Indonesia.

\section{Bibliography}

\section{Books}

Akib, Muhammad, Politik Hukum Lingkungan: Dinamika Dan Refleksinya Dalam Produk Hukum Otonomi Daerah, PT RajaGrafindo Persada, Jakarta, 2012.

Asshiddiqie, Jimly, Green Constitution: Nuansa Hijau Undang-Undang Dasar Negara Republik Indonesia Tahun 1945, Rajawali Pers, Jakarta, 2010.

Mahfud MD, Moh., Politik Hukum di Indonesia, Edisi Revisi, Rajawali Pers, Jakarta, 2009.

Saifudin, Partisipasi Publik Dalam Pembentukan Peraturan Perundang-Undangan, FH UII Press, Yogyakarta, 2009.

\section{Articles of Journal}

Absori, "Deklarasi Pembangunan Berkelanjutan dan Implikasinya di Indonesia", Jurnal Ilmu Hukum, Vol. 9, No. 1, Maret 2006: 39 - 52, UMS, Surakarta

Banisar, David et all, "Moving From Principles To Rights: Rio 2012 And Access To Information, Public Participation, And Justice", Sustainable Dev. L. E Pol'y, (Spring, 2012).

Changhua, Wu, "Improving The Legal And Policy Foundation For Public Access To Environmental Information In China," Vol, 24, Temp. J. Sci. Tech. \& Envtl. L. Spring, 2005.

Dellinger, Marianne “Ten Years Of The Aarhus Convention: How Procedural Democracy Is Paving The Way For Substantive Change In National And International Environmental Law", Vol. 23, Colo. J. Int'l Envtl. L. E Pol'y, (Summer 2012).

Panjaitan, Saut P., “Jaminan Perlindungan Konstitusional Hak Tiap Orang Untuk Memperoleh Informasi dan Berkomunikasi", Jurnal Simbur Cahaya, Vol. XV No. 42 Mei 2010, Unit Penelitian FH Universitas Sriwijaya Palembang.

Toth, Bende, "Public Participation and Democracy in Practice Aarhus Convention Principles as Democratic Institution Building in The Developing World", Vol. 30, J. Land Resources E Envtl. L, (2010), 


\section{Magazines}

Pasaribu, H. Bomer, “Arah Pembangunan Hukum Menurut UUD 1945 Hasil Amandemen Dari Perspektif Legislasi, Badan Pembinaan Hukum Nasional Departemen Hukum dan HAM RI", Majalah Hukum Nasional (1), 2007.

\section{International instrumens}

Aarhus Convention, 1998.

Rio Declaration, 1992.

\section{National Instruments}

The 1945 Constitution

Act No. 32 of 2009, regarding Environmental Protection and Management Act (State Gazette of The Republic of Indonesia of 2013 No. 112, Additional State Gazette of The Republic of Indonesia No. 5059).

Act No. 39 of 1999 regarding Human Right Act (State Gazette of The Republic of Indonesia of 1999 No. 165, Additional State Gazette of The Republic of Indonesia No. 3886).

Act No. 14 of 2008 regarding the Openness of Public Information Act (State Gazette of The Republic of Indonesia of 2008 No. 61, Additional State Gazette of The Republic of Indonesia No. 4846).

Act. No. 25 of 2009 regarding Public Services Act (State Gazette of The Republic of Indonesia of 2009 No. 112, Additional State Gazette of The Republic of Indonesia No. 5038).

Act No. 12 of 2011 regarding the Establishment of Laws and Regulations Act (State Gazette of The Republic of Indonesia of 2011 No. 82, Additional State Gazette of The Republic of Indonesia No. 5234).

\section{Internet}

http:/ / pustaka.unpad.ac.id/archives/131720/, accessed on 10 Oktober 2015.

Johan Kurniawan, Transformasi Partisipasi Publik dalam Perumusan Kebijakan di Era Reformasi, terdapat dalam http://setkab.go.id/transformasipartisipasi-publik-dalam-perumusan-kebijakan-di-era-reformasi/, diakses tanggal 20 Agustus 2016.

Open Working Group on Sustainable Development Goals (United Nations), "Access to Justice in environmental matters for sustainable development Contribution of the Société de Legislation Comparée to the Open Working Group on Sustainable Development Goals (United Nations)", http: / / www.legiscompare.fr/site-web/IMG/pdf/A2J_SLC.pdf Retrieved on 10 October 2015.

TIFA, "Fulfilling the Right to Information Baseline Assessment on Access to Information in East Nusa Tenggara", https://www.article19.org/ 
data/files/pdfs/publications / fulfilling-the-right-to-information.pdf. Retrieved on 10 October 2015. 